
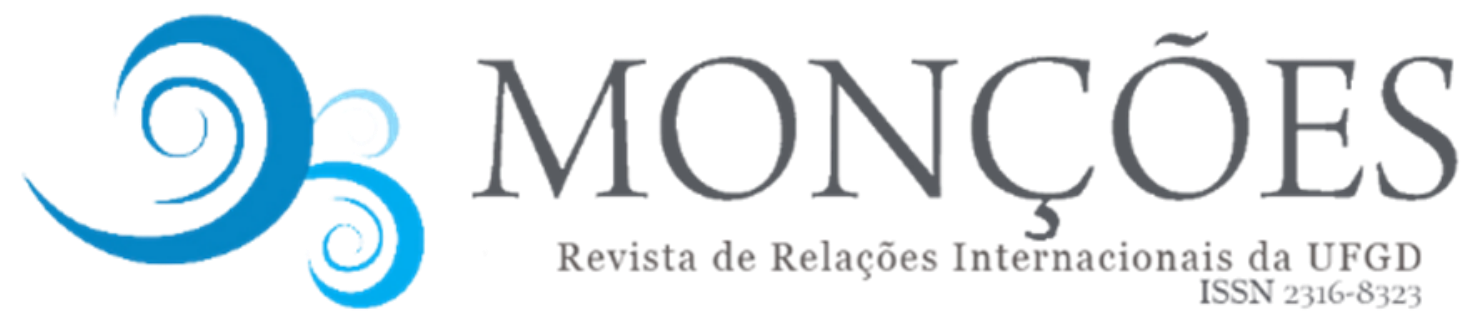

Revista de Relações Internacionais da UFGD

ISSN 2316-8323

\title{
A AMAZÔNIA SEM FUTURO OU O FUTURO SEM A AMAZÔNIA
}

\author{
BRENDA THAINÁ CARDOSO DE CASTRO \\ Professora adjunta do curso de Relações Internacionais da \\ Universidade da Amazônia (UNAMA), Belém (PA), Brasil. \\ ORCID: https://orcid.org/0000-0001-8081-0406
}

brendatcc@gmail.com

\begin{abstract}
RESUMO: O presente artigo convida a uma inflexão a partir de debates nas Relações Internacionais de percepções temporais e espaciais como universais, ao questionar como análises e referências do imaginário sobre a Amazônia são indissociáveis das dinâmicas citadas. Para tanto, aborda-se a história e o teor das políticas voltadas para a Amazônia, com ênfase no governo de Jair Bolsonaro e nas contestações de povos indígenas contra o projeto de nação desenvolvimentista. Ao reconhecimento de um agravamento de políticas nocivas à região são apresentados também visões de sujeitos que têm recorrido a um cenário imaginário de destruição ou fim da Amazônia. As formas de se pensar sobre futuros, fins e lugares partem de uma referência que é predominantemente centrada em valores ocidentais. A partir de outras percepções culturais, podemos imaginar novas formas de ver o mundo, a Amazônia e as Relações Internacionais.
\end{abstract}

PALAVRAS-CHAVE: Amazônia. Futuro. Segregação Geopolítica.

\section{THE AMAZON WITHOUT A FUTURE OR THE FUTURE WITHOUT THE AMAZON}

ABSTRACT: This article invites to an inflection based on debates in International Relations on temporal and spatial perceptions as universal, by questioning how analyzes and references of the Amazon's imagery are inseparable from the dynamics mentioned. To this end, the history and content of policies aimed at the Amazon are addressed, with an emphasis on the government of Jair Bolsonaro and on the challenges of indigenous peoples against the project of nation based in developmentalism. From the recognition of a worsening of harmful policies in the region is also presented visions of individuals who have resorted to an imaginary scenario of destruction or end of the Amazon. Ways of thinking about futures, ends and places start from a reference that is predominantly centered on western values. From other cultural perceptions we can imagine new ways of seeing the world, the Amazon and International Relations.

KEYWORDS: Amazon. Future. Geopolitical segregation.

\section{LA AMAZONÍA SIN FUTURO O EL FUTURO SIN LA AMAZONÍA}

RESUMEN: Este artículo invita a una inflexión desde los debates en Relaciones Internacionales de las percepciones temporales y espaciales como universales, al cuestionar cómo los análisis y referencias del

Monções: Revista de Relações Internacionais da UFGD, Dourados, v.9, n.18, jul./dez. 
imaginario sobre la Amazonía son inseparables de las dinámicas mencionadas. Para ello, se aborda la historia y el contenido de las políticas dirigidas a la Amazonía, con énfasis en el gobierno de Jair Bolsonaro y en los desafíos de los pueblos indígenas frente al proyecto de nación desarrollista. En el reconocimiento de un agravamiento de políticas nocivas en la región también se presentan visiones de sujetos que han recurrido a un escenario imaginario de destrucción o fin de la Amazonía. Las formas de pensar sobre futuros, fines y lugares parten de una referencia que se centra predominantemente en los valores occidentales. Desde otras percepciones culturales, podemos imaginar nuevas formas de ver el mundo, la Amazonía y las Relaciones Internacionales.

PALABRAS CLAVE: Amazonía. Futuro. Segregación geopolítica.

\section{INTRODUÇÃO: O PASSADO À FRENTE E O FUTURO ATRÁS}

Parece algo natural para boa parte da população mundial que o tempo seja visto da seguinte forma: o passado, o que já aconteceu, ficou para trás; o presente, o agora, é o que está sendo vivido; e o futuro é aquilo que ainda não aconteceu, o que nos aguarda. Tal noção linear, e até mesmo de certo modo "progressista", está enraizada nas estruturas das sociedades atuais.

Apesar de vivermos em um mundo em que tal lógica se mostra predominante e se afirma como horizonte para a humanidade, outras formas de ver o mundo, o lugar e o tempo existem. Julieta Paredes e Adriana Guzmán (2014) abordam como para o povo Aymara o tempo é entendido de forma diferente. O futuro não estaria à frente, posto que não podemos vê-lo. Mas sim o passado, esse que vemos e sabemos o que aconteceu, logo molda os rumos que tomamos. Do mesmo modo que, pela lógica, o futuro, enquanto algo que não se vê, estaria atrás. Para os Munduruku, existem apenas dois tempos: o do passado e do presente. O futuro não existe, já que este não chega a se materializar, existindo apenas o presente, o que se vive, e o passado, o que se viveu (MUNDURUKU, 2012).

Tais referências assentam este artigo sobre a premissa da desestabilização de noções dadas e naturalizadas sobre temporalidade e territorialidade nas relações internacionais. Tudo envolvido nessas dinâmicas parece fazer sentido em um futuro imaginado: a sobrevivência do Estado, o destino da nação e 0 apogeu do desenvolvimento. Narrativas estas embebidas em premissas temporais que se materializam em lugares, territórios e corpos. É uma versão construída e instituída a partir 
de um processo histórico que data da colonização europeia pelo mundo, pela expansão de seus modelos de organização política, econômica e sociocultural.

Convido aqui a um exercício de repensar como as Relações Internacionais partem de premissas presentes, porém invisíveis, sobre temporalidade para pensar as relações de poder (AGATHANGELOU E KILLIAN, 2016). Questiona-se aqui de que forma tais produções de desejos políticos são projetadas em lugares imaginados na ideia de nação (ANDERSON, 2008), enquanto produtos históricos de processos que moldaram as relações internacionais contemporâneas, como a colonização, o imperialismo e outras dinâmicas, no que Agathangelou e Ling (2009) definem como segregação geopolítica.

Tais desestabilizações possibilitam traçar a relação entre temporalidade e colonialidade (QUIJANO, 2005) para reavaliar como o imaginário produzido sobre a subjetividade da Amazônia tem sido inventado nos últimos séculos por meio da imposição de um projeto nacional no qual esta é situada em três imagens: i) o Eldorado com riquezas e recursos capazes de tornarem o Brasil, enfim, o país do futuro; ii) a região responsável pelo atraso, vazio demográfico e obstáculo ao desenvolvimento nacional; e, por fim; iii) o "patrimônio da humanidade" e bem comum, que deve ser "protegido" e "salvo" - em tom que muitas vezes remete ao "fardo do homem branco". Apesar de propostas diferentes, as lógicas que embasam tais imagens possuem similaridades nos valores inerentes às estruturas sociais nas quais se desenvolvem e no apagamento da agência de sujeitos e sujeitas amazônidas.

Em seguida, acontecimentos relativos aos últimos anos no Brasil, com ênfase no governo de Jair Bolsonaro, são abordados a partir de notícias, reportagens, mas também pela perspectiva de documentos produzidos pelo povo Munduruku. Aponta-se como o cenário que se desenrolou nesse período é marcado pela intensificação de práticas intrínsecas ao projeto nacional e como este tem provocado exercícios de imaginação temporais sobre a região, intensificando a preocupação e o interesse com: o futuro da Amazônia, um futuro, uma humanidade ou um mundo sem a Amazônia. Isto é realizado apoiando-se em questionamentos sobre as próprias noções de "mundo" e "humanidade" (DANOWSKI E VIVEIROS DE CASTRO, 2017; KOPENAWA E ALBERT, 2015; KRENAK, 2019). 
Procura-se aqui reverberar para além da superfície da forma como a região é imaginada, propondo pensá-la a partir de sua profundidade e das próprias possibilidades nela vividas. Podemos inclusive questionar a sua própria existência enquanto "Amazônia".

\section{POR QUE TU PENSAS TANTO NO FUTURO?}

"Por que tu pensas tanto no futuro?" - foi o que me indagou Rosivaldo, morador da comunidade de Jamaraquá, na Floresta Nacional do Tapajós, no ano de 2017. A pergunta se deu em uma trilha que fazia com ele pela floresta ${ }^{1}$, um dos passeios oferecidos pela associação da comunidade, que trabalha com turismo de base comunitária.

Enquanto andávamos pela íngreme trilha, perguntei a Rosivaldo o que ele pensava sobre o futuro e ele me interpelou sobre a origem do meu interesse por esse assunto. Não era algo que ele pensava tanto, pelo menos não nos termos em que eu colocava. Essa inquietação me acompanhou durante o aprofundamento de leituras sobre a Modernidade/Colonialidade ${ }^{2}$, de modo que pude identificar como a minha própria subjetividade estava localizada em um contexto em que, para mim, tal forma de pensar era algo já naturalizado e universalizado.

A forma de relacionar diretamente futuro-desenvolvimento-progresso pode ser identificada como a lógica moderna/colonial. A modernidade é tida como propósito universal e resultado de uma evolução linear, um futuro/avanço de um lugar específico (Europa); localizando tudo aquilo que não é "moderno" como o seu oposto - atrasado, primitivo. Quijano (2005) indica que a colonialidade é o outro lado da modernidade, visto

\footnotetext{
${ }^{1}$ Eu estava hospedada na casa da família de Rosivaldo e Nice e estava iniciando a pesquisa de campo para o que viria a ser minha tese de doutorado. Eu pretendia abordar perspectivas de futuro de moradores da região do Tapajós, especialmente por conta da previsão do Complexo Hidrelétrico do Tapajós. Minha intenção era traçar como o projeto de nação e o desenvolvimentismo se relaciona com as perspectivas dos indivíduos que vivem nos lugares onde tais lógicas se materializam, sob a justificativa de "interesse nacional".

${ }^{2}$ Ballestrin (2013) identifica que o Grupo Modernidade/Colonialidade foi criado no final dos anos 1990 por estudiosos latino-americanos que residiam nos EUA e buscavam rupturas com referências colonizadoras e o reconhecimento do processo de colonização de modo diferenciado no tocante à América Latina, considerando que data desde 1492 e não apenas a partir da "modernidade europeia". O grupo se diferencia de iniciativas anteriores como dos estudos literários e culturais sobre pós-colonialismo em universidades dos EUA e da Inglaterra e do Grupo de Estudos Subalternos no sul asiático.
}

Monções: Revista de Relações Internacionais da UFGD, Dourados, v.9, n.18, jul./dez. 72 
que esta não poderia existir sem as condições materiais fruto da colonização e exploração de outros povos; afirma ainda que esses processos não findaram com o rompimento formal da relação colonial, mas se mantiveram pelas estruturas produzidas por ela.

A colonialidade do poder (QUIJANO, 2005), entendida como a dominação e estratificação social e exploração do trabalho pautada numa definição de "raça" - mas também de "gênero" (LUGONES, 2014) - possibilita analisar como tais referências geram sociedades, estruturas e subjetividades a partir da premissa radical da hierarquização de saberes e corpos a partir de noções ocidentecentrências.

A discussão sobre Modernidade/Colonialidade auxilia a pensar como a temporalidade, a formação dos Estados nacionais pós-coloniais e suas estruturas se dão a partir da reprodução de referências universalizadas sobre tempo, espaço, saberes e corpos. Isso é perceptível, por exemplo, no discurso de "desenvolvimento" que se mescla com a ideia de progresso, de esforço individual e trata como um processo evolucionário - e até mesmo fatalista (LAPA, 2018) - a acumulação de riquezas e melhoria da vida nos termos capitalistas e liberais. Rist (2008) identifica isso como uma forma de "fé global", enquanto pode ser visto para a América Latina como um sonho, uma promessa, mas também um fantasma que assombra a região (ESCOBAR, 2007; DUSSEL, 2005).

Logo, a linearidade da compreensão do tempo, identificando o futuro como aquilo que deve ser controlado e dominado (AGATHANGELOU E KILLIAN, 2016) por meio da racionalidade, da ciência e da técnica - "modernidade" -, possui lastro nas fundações que produzem as nossas subjetividades. Frantz Fanon (2008) contempla tal discussão ao avaliar como a colonização se dá em um duplo processo de complexo de inferioridade: econômico e de interiorização/epidermização da inferioridade. Deste modo, produz-se o desejo de ser "desenvolvido" associando a noção econômica a uma superioridade racial; o que também passa a ser reproduzido na ideia de nação, onde as narrativas de um destino comum e um passado compartilhado (YUVAL-DAVIS, 1997) ensejam um desenvolvimento enquanto futuro glorioso ${ }^{3}$.

\footnotetext{
${ }^{3}$ Tal mentalidade se consolida nas relações internacionais especialmente a partir do discurso do então presidente estadunidense, Harry Truman, em 1949. (ESCOBAR, 2007)
} 
As Relações Internacionais (RI) reproduzem tal naturalização nos seus debates, principalmente porque a produção da disciplina vem majoritariamente de regiões que concentram recursos de poder; de onde viriam fórmulas e respostas para as nações "menos favorecidas", com recomendações para se inserirem no mundo globalizando e competirem igualmente com as demais. A criação de organismos internacionais, como as Nações Unidas e o Banco Mundial, que produzem normas e índices que classificam o desempenho, tem sido ferramenta de legitimação da fé global no desenvolvimento como realizável por todos.

Podemos perceber como nesses espaços o tempo é um fator invisível, mas tido como natural, permeando as análises políticas sem reconhecer como se toma o tempo como universal, unilinear, o qual deve ser controlado e dominado ou, melhor dizendo, colonizado (AGATHANGELOU E KILLIAN, 2016). Assim, o projeto de nação em si e a modernidade/colonialidade, pela lógica do desenvolvimento e do progresso, passam por referências temporais. As políticas adotadas a partir desse pensamento nada mais são do que formas de tentar controlar tal tempo, projetando em algum tipo de "futuro" a realização de satisfações e desejos.

Agathangelou e Killian (2016) chamam atenção para como a temporalidade que marca as produções de conhecimento nas relações de poder e na política envolvem a violência e a morte como ferramentas para controlar o tempo, justificando tais práticas como aceitáveis visando a perenidade almejada para o Estado. Por isso, outras formas de violência são representadas como ameaça, ao não coadunarem com seu objetivo. Daí a relação com Frantz Fanon, o qual indica como o tempo vai ser também um mecanismo de colonização. Para os autores, a ficção do tempo é como uma força que coproduz subjetividade e que é empregada como um dispositivo de poder regulatório (colonial, neocolonial, imperial ou outro).

Enquanto o Estado-Nação se coloca como um projeto de futuro, de destino comum compartilhado por seus habitantes, que, pretensamente, uniria os seus interesses em torno de um bem comum, o desenvolvimento é tido enquanto um modelo, um processo e também um estágio final a ser alcançado, mas que afetará os sujeitos de acordo com posicionalidades de classe, gênero, raça e outras. 
Sujeitos e instituições são, nesse sentido, orientados sob tais condições a pensarem o tempo a partir de uma ideia linear, indissociável das estruturas sociais e valores enraizados. Desde crianças, nas sociedades sob tais signos, a preocupação deve ser o futuro, desenvolver-se, enriquecer, melhorar de vida numa perspectiva materialista. Tal forma de se ver no mundo não é natural ou universal, mas produzida, por uma dinâmica moderna/colonial. Por isso, pude entender porque eu pensava tanto no futuro nesses moldes. Isto nos possibilita identificar de que forma naturalizamos tais referências e como essas mesmas bases produzem não apenas subjetividades de indivíduos, mas também de lugares, como a Amazônia.

\section{ONDE FICA A AMAZÔNIA?}

Eu via a Amazônia através do olhar da televisão, da Globo, do Globo Repórter, sempre tinha a sexta-feira que falava da floresta e noutro dia era um assunto, que não tinha nada a ver. Eu ficava esperando; e eu olhava aquilo fascinada, "onde será que é isso?", não sabia... Porque mesmo na escola, na universidade, a gente não teve esse olhar assim pra floresta como um ambiente... com pessoas, populações inteiras morando aqui... Sempre foi muito comercial essa ideia que eles davam pra gente sobre como utilizar esses recursos da melhor forma e quando eu abro o mapa já trabalhando com turismo, já começo a olhar a minha região, "pô, tô no meio dela, tô praticamente no coração da Amazônia" e não me sentia amazônida, apesar de estar aqui... (Lalah, entrevista realizada em 17 de julho de 2018 em Alter-do-Chão).

Lalah, que é Borari e mora em Alter-do-Chão no Pará, relatou sobre o processo de se entender enquanto amazônida e de viver na Amazônia. A sua experiência nos leva a pensar como noções espaciais e geográficas que parecem extremamente naturais para muitos também envolvem diferentes formas de relação de pertencimento e reconhecimento.

A origem da nomeação desse território que hoje reconhecemos como "Amazônia" remonta a relatos do século XVI (CARVAJAL, ROJAS E ACUÑA, 1941) conhecidos por sua descrição das mulheres guerreiras que viviam no rio Nhamundá, localmente chamadas de Ycamiaba, as quais foram descritas como mulheres altas, de pele clara e com apenas um seio, vivendo em comunidades exclusivas para mulheres. Suas descrições lembraram o mito grego das mulheres guerreiras amazonas, daí "Amazonas" ser o nome dado ao rio que flui do Peru para o Oceano Atlântico. O nome do rio 
Amazonas consolidou-se entre os séculos XVIII e XIX ${ }^{4}$ com a transposição do termo para se referir a toda uma região. O que seria, então, a Amazônia?

Ao ouvir ou ler o termo "Amazônia" é possível que o cérebro de quem o ouça imediatamente dispare diversas imagens, sentimentos e percepções prévias. Fascínio, contemplação, medo, desconhecimento. A palavra atualmente difundida e utilizada para se referir a um bioma e a uma região, foi estabelecida por colonizadores a partir de uma mistura de relato real e mito fundacional sobre mulheres que viveriam em uma sociedade matriarcal, seriam guerreiras e teriam apenas um seio - características que apontam para diversas possibilidades da origem etimológica da palavra no grego e também na língua jônica.

Neide Gondim aponta como "a Amazônia é o mistério inventado pelos europeus" (Gondim, 2019, p. 157), através dos relatos de viajantes, colonizadores, freis e padres, cientistas, naturalistas, cronistas e também de ficcionistas. Ela frisa que permeiam os escritos referências que oscilam entre o edenismo e o infernismo, ou seja, entre o deslumbramento e o assombro.

Desde então, a Amazônia tem sido muitas vezes representada como um lugar imaginário fantástico e exotizado por muitas pessoas que não a conhecem, mas que muito já ouviram ou viram imagens e reportagens sobre suas grandezas e riquezas; e, para outros tantos, que já a conheceram, e continuam a enxergar a região de tal forma por lentes coloniais. Na verdade, ela é a terra de mais de 67 milhões de pessoas, de diversas etnias e culturas, considerando toda a Pan-Amazônia que engloba 9 países.

Dessa forma, a região, que não era habitada por um povo homogêneo único, carrega ainda hoje os efeitos e símbolos dessa denominação. Enquanto isso, os povos originários atribuíram outros nomes para se referir ao lugar, como a Mundurukânia para os Munduruku, entre tantas outras referências que dialogam com recortes territoriais díspares do que se entende como Amazônia Legal. As relações de identidade, memória e pertencimento não se formaram de cima para baixo, como nas empresas colonialistas

\footnotetext{
${ }^{4}$ Diversas figuras contribuíram para a difusão do termo e da ideia de generalidade da região precisamente no século XIX, como a definição de Hiléia proposta pelo cientista prussiano e naturalista Alexander Von Humboldt; a expressão "País das Amazonas" por Ignacio Accioli Cerqueira e Silva em 1833. (FIGUEIREDO, CHAMBOULEYRON E ALONSO, 2017)
} 
que renomearam lugares e culturas como parte de uma estratégia de dominação por meio da assimilação.

Pensar o mundo enquanto Norte-Sul, Leste-Oeste, Ocidente e Oriente são referências consolidadas para muitos, assim como as regiões do Brasil e a própria fronteira do território nacional em si. Tais noções, contudo, não são neutras, como Edward Said (2007) já apontava ao abordar a construção discursiva feita pelo Ocidente na invenção do que seria um "Oriente".

O "Oriente" enquanto lugar imaginário é produzido a partir da projeção do oposto, daquilo com que o ocidente não se identificava e aquilo que não queria ser, ou seja, o "Outro". É a partir de dinâmicas similares que hoje temos as referências geopolíticas que organizam as relações internacionais não apenas em torno das fronteiras dos Estados, mas também em continentes e regiões como Norte, Sul, Leste e Oeste. Tais referências se projetam nas mentes de estudiosos, acadêmicos, líderes políticos e são reproduzidas por muitas ferramentas como a mídia e a própria "ciência".

Anna M. Agathangelou e Heather M. Turcotte (2010) destacam como a definição de Norte-Sul - extensível aos outros exemplos citados - foi e é territorialmente marcada por histórias de luta e segregação, não sendo naturais e espontâneas. Enquanto a segregação geopolítica tenta "isolar" características, fenômenos e problemas, restringindo-os a alguns lugares, na realidade, os padrões desiguais de migração são perceptíveis, assim como nas relações de trabalho e outros tantos processos que desafiam essas definições rígidas e fixas, mostrando suas rachaduras.

Assim, sendo um dos pontos de partida dessa reflexão, a discussão sobre a segregação geopolítica (AGATHANGELOU E LING, 2009) a expõe como uma forma de solidificar as condições de poder que regulam, controlam e exploram os corpos como centrais para as reformas neocolonialistas da prática política e da produção de conhecimento.

Logo, os assuntos e sujeitos das RI são negociados por meio de geografias divididas de poder dentro da disciplina, em nome de projetos que centralizam o lucro e 0 medo como seus objetivos (ibid., p. 29). Deve-se então considerar que as RI enquanto campo de estudo, disciplina e práticas têm como base a "segregação geopolítica de 
corpos, povos, terras e conhecimento para manter as estruturas de poder" (AGATHANGELOU E TURCOTTE, 2010, p. 46).

Na Amazônia, observa-se como a região tem sido historicamente localizada enquanto um espaço tido como atrasado, subdesenvolvido e primitivo, ao mesmo tempo em que rico e receptáculo do projeto de nação de crescimento econômico. A leitura do lugar como "atrasado" normalmente se funde a uma visão racializada e de vazio demográfico, por ser ocupada predominantemente por grupos inferiorizados e cujos modos de vida e existência, conhecimentos e organizações não são legitimados no projeto de nação, de modo que são localizados não apenas em um lugar circunscrito espacialmente, mas também referentes a um tempo passado.

Aqui proponho que repensemos as RI, mas também a própria ideia de Amazônia, constituída no âmago da formação do atual sistema internacional. Posto que a "invenção da Amazônia" é indissociável das relações internacionais, a própria área e as dinâmicas nela imbricadas imaginam-se, produzem-se e reproduzem-se dentro da lógica geopolítica da segregação na qual a região amazônica também é localizada.

Não se pode afirmar que a Amazônia sempre existiu enquanto lugar, região ou bioma, muito menos que haja uma unidade cultural e étnica. Entretanto, com o passar do tempo, as práticas e políticas embebidas no desenvolvimentismo e na colonialidade destinadas à região, lida como "primitiva", "atrasada", "despovoada" (PORTOGONÇALVES, 2015), tiveram como outro lado a construção identitária da relação de pertencimento para além dessas limitações, sendo a Amazônia não apenas um lugar de denominação exógena, mas também um lugar de onde se produzem subjetividades outras, de todas as histórias que se escrevem nela. Isso pode ser percebido, por exemplo, em articulações dos povos da região como o Foro Social Panamazônico (FOSPA, 2020) ${ }^{5}$.

O que se entende então por Amazônia é fruto da própria produção de subjetividades capitalísticas (GUATTARI E ROLNIK, 1996), que atribui significados a sujeitos, mas também a instituições e lugares, como a Amazônia. Por isso, a região é

\footnotetext{
${ }^{5}$ O FOSPA é uma iniciativa de articulação que envolve povos do Brasil, Peru, Bolívia, Equador, Colômbia, República Cooperativa da Guiana, Suriname e Guiana francesa. Os princípios que guiam o fórum são a luta antiimperialista, construir ações e estratégias críticas ao modelo de "desenvolvimento" predatório. Fazem parte da iniciativa povos indígenas e tradicionais, movimentos e organizações sociais destes povos e outras comunidades. Site oficial: http://www.forosocialpanamazonico.com/pt/em-FSPA/
} 
percebida ora como fonte de recursos naturais (objeto de exploração), ora como patrimônio da humanidade (PORTO-GONÇALVES, 2015), mas ainda assim sob uma lógica capitalista, de propriedade.

Tal visão tem conduzido as políticas para a região desde a colonização até a imposição do projeto nacional - como uma forma de colonialismo interno (GONZÁLEZ CASANOVA, 2006). Um marco importante dessas políticas já mais intensificadas para a Amazônia é a política adotada pelo Marquês de Pombal no século XVIII, visando uma ocupação efetiva da região. Já pelo fim do século XIX, é com o ciclo da borracha (18791912) que intensos fluxos de migração e um maior protagonismo econômico nacional e internacional levaram a uma maior atenção das elites brasileiras para a Amazônia.

Referências coloniais e de um imaginário amazônico de Eldorado foram basilares e impulsionadoras de migrações em buscas de terras e riquezas, vendo a Amazônia como um lugar vazio, terra de ninguém, que deveria ser ocupada, explorada e desenvolvida. Tal dinâmica se intensifica a partir do governo de Getúlio Vargas, na adoção de um viés desenvolvimentista mais estruturado projetado para o norte do País.

Com o fim do governo de Vargas em 1954, inicia-se um período no Brasil em que a predominância do discurso político é mais uma vez pautada no desenvolvimento e na modernização, mas com políticas mais ambiciosas que as anteriores. É também o momento do início da Guerra Fria e a pressão estadunidense pelo retorno do alinhamento automático na política externa brasileira, levando a pressionar governos como o de Juscelino Kubitschek, Jânio Quadros e João Goulart. Entretanto, é com o golpe de 1964 e a instauração da ditadura civil-militar que seguirá nas décadas seguintes, que será consolidado um projeto de nação pautado em políticas desenvolvimentistas voltadas para a Amazônia enquanto uma colônia interna.

É nesse momento que o caráter de ocupação e defesa contra uma possível internacionalização da Amazônia leva a políticas como a de "integrar para não entregar" e a de "terra sem homens para homens sem terra". Tais políticas tiveram como consequência o período mais intenso de ocupação - e também de destruição do bioma -, assim como a intensificação dos conflitos rurais entre colonos, indígenas, latifundiários e as demais populações que já viviam no território. 
Foram planejados e implementados também megaprojetos para a região por meio de políticas que mudaram a base econômica produtiva, que até hoje é marcada pela pecuária extensiva, a mineração e a extração de madeira em nível industrial. Todos esses processos foram decisivos e responsáveis pelos altos índices de desmatamento na região nas últimas décadas e envolveram também violentos embates com populações indígenas, ribeirinhos e trabalhadores rurais. Tal contexto fez dos conflitos e da grilagem práticas comuns da região, consolidando a questão fundiária e o conflito agrário como cernes da questão política e econômica (LOUREIRO E PINTO, 2005).

A socióloga amazônida Violeta Loureiro (2014) destaca que as políticas adotadas na época eram embasadas numa lógica de projeto de desenvolvimento nacional que o Estado apresenta "como elemento mobilizador e ético de suas ações para o "bem-estar comum", o "progresso", "a modernização" da região. (...) Sob o rótulo de um propalado “interesse nacional” (LOUREIRO, 2014, p. 85)6.

Márcio Souza (2015, p. 159) também destaca como o modelo de desenvolvimento na Amazônia combinou: o direcionamento para uma "ocupação territorial por parte de proprietários não residentes na região"; a tendência a priorizar projetos agropecuários sobre os industriais; e, "a negação da Amazônia aos seus próprios habitantes". Destarte, ele define que as políticas para a região desde o século passado provocaram na Amazônia apenas um "espasmo capitalista" (id.).

Concordante à emergência cada vez mais institucionalizada da discussão ambiental e do pan-indigenismo, as tensões políticas na América Latina no contexto da Guerra Fria e as preocupações nacionais também proliferavam. Em 1978, o Brasil, a Bolívia, o Peru e o Equador viviam em ditaduras, enquanto os demais países passavam por instabilidades políticas internas. Naquele ano, com a intenção mais uma vez de integrar, firmou-se o Tratado de Cooperação Amazônica (TCA), que primava pela soberania e defesa da região. Era também uma resposta ao "fantasma da internacionalização", ainda que concomitantemente se tenha implementado o Programa Grande Carajás (PGC) em parceria com multinacionais (CONGILIO E IKEDA, 2014).

${ }^{6}$ Presente, por exemplo, na criação da Zona Franca de Manaus (ZFM) pela Lei № 3.173 de 1957, a Operação Amazônia de 1966 a 1967, no Programa de Integração Nacional (PIN) de 1970, nos Planos de Desenvolvimento da Amazônia (I PDA de 1972, II PDA de 1975-1979 e o III PDA de 1980-1985). 
A iniciativa avançou pouco nas décadas seguintes, sendo transformada em Organização do Tratado de Cooperação Amazônia (OTCA) apenas nos anos 2000, já adquirindo um caráter mais voltado para o meio ambiente e se afastando do discurso de soberania e defesa. Contudo, o projeto desenvolvimentista não arrefeceu do mesmo modo. O Programa de Aceleração do Crescimento (PAC I e PAC II), lançado em 2007 durante o Governo Lula, manteve as características históricas de modus operandi do desenvolvimento para a Amazônia, com ênfase em infraestruturas (novas estradas e rodovias) e energia (os planos para novas hidrelétricas); no Governa Dilma, além do enfraquecimento das políticas ambientalistas, destaca-se também o famigerado e ultrajante caso da Hidrelétrica de Belo Monte, em Altamira.

A política de matriz energética baseada em hidrelétricas no Brasil também é fruto do projeto nacional idealizado no âmbito da ditadura, demonstrando que mesmo com alternâncias políticas, ideológicas e partidárias no poder executivo, a essência do Estado capitalista nas dinâmicas pós-coloniais mostra-se estável na reprodução do colonialismo interno (GONZÁLEZ CASANOVA, 2006) ou do neocolonialismo (FANON, 1968), assim como da colonialidade. Houve pequenas diferenças em questões como mais ou menos incentivo à representação ou participação política, mas os casos de violência, abuso e políticas desenvolvimentistas estão presentes em todos os governos aqui citados.

Apesar disso, é preciso destacar como tal processo é permeado por nuances. Por exemplo, a partir da redemocratização houve grande conquista de movimentos sociais no âmbito da demarcação de terras, da instituição de políticas ambientais nacionais - mas continuaram recorrentes os casos de violência, massacres e assassinatos na região. (LOUREIRO, 2014; CPT, 2017)

A Amazônia, enquanto região inventada, existe no imaginário, mas as políticas que se formam a partir da lógica moderna/colonial se materializam nessa região, circunscrita no projeto nacional e delimitada geograficamente, a ponto de produzir uma realidade. Ainda que para parte da população local as suas relações de pertencimento se deem com a floresta em $\mathrm{si}$, ou com os rios dos quais vivem e outras referências identitárias, e não com a palavra Amazônia, a invenção da Amazônia localizou toda a sua população no projeto de nação, de modo que são todos envolvidos nos efeitos dessa 
mentalidade. Ainda assim, tal processo não se dá de forma passiva e é recorrente a ressignificação da ideia de "Amazônia" pelos povos que nela vivem.

Ademais, é comum ser feita uma relação direta da Amazônia com os povos indígenas em uma destas "imagens" inventadas. O efeito é o de se criar uma imagem da Amazônia como região etnicamente homogênea e indígena, ignora-se a diversidade cultural da região e do próprio Brasil. Tal racialização da subjetividade da Amazônia também envolve a tentativa de invisibilização da situação de povos indígenas em outras regiões do país. Atrelando-se uma naturalização da associação de indígenas à Amazônia e não às outras regiões do Brasil, que não são "pensadas" desta forma, influenciam-se políticas e discursos sobre as mesmas, sobre suas demandas e necessidades.

Os desdobramentos dessa mentalidade podem ser percebidos nos últimos anos pelo agravamento de discursos e políticas referentes tanto à Amazônia quanto a todos os povos indígenas no Brasil. Isso está presente na fala não apenas dos principais dirigentes do Estado, e é reproduzido por parte da população, ONGs e pela comunidade internacional.

\section{A AMAZÔNIA SEM FUTURO}

Embora em governos anteriores a lógica desenvolvimentista tenha continuado em linhas gerais, abrandando-se em âmbitos específicos - como o avanço de demarcação de Terras Indígenas e criação de Unidades de Conservação - nota-se um adensamento das políticas desenvolvimentistas para a Amazônia a partir do golpe político-parlamentar que levou ao impeachment da então presidenta Dilma Rousseff em 2016, levando ao cargo o vice-presidente Michel Temer. É necessário pontuar como tal processo tem levado a um aumento da preocupação e do interesse pela região e que muitos especialistas e representantes dos povos têm alertado para uma ameaça real à sobrevivência da vida e da floresta.

Do governo Temer destaca-se o enfraquecimento de políticas ambientais, como no caso do decreto no 9.142 que extinguiu a Reserva Nacional de Cobre e Associados (Renca), criada em 1984, permitindo a exploração privada de minérios. A mesma se localiza entre os estados do Amapá e do Pará, abarcando também parte da Terra Indígena Waiãpi. $O$ decreto foi criticado por especialistas, parte da população e 
representantes de movimentos sociais, levando à revogação ainda em setembro de 2017 pelo presidente. Outra decisão catastrófica, da qual não houve recuo, foi a extinção do Programa Bolsa Verde, que desde 2011 oferecia um auxílio de $R \$ 300,00$ (trezentos reais) a cada três meses por família que vivesse em situação de extrema pobreza em assentamentos, reservas extrativistas e área ribeirinha, como forma de compensar e incentivar o compromisso das famílias com a proteção da natureza e garantir um modo de vida nas condições locais. O fim do programa deixou mais de 50 mil pessoas vivendo em situação de extrema pobreza (ÂNGELO, 2018).

Em uma carta de novembro de 2016, as Mulheres Munduruku do Alto e Médio Tapajós denunciaram o processo de desmonte das políticas voltadas para os povos indígenas em todo o Brasil, enfatizando a situação na Amazônia. Essa denúncia apontou a centralidade da defesa do território contra as políticas do Estado brasileiro desde a colonização, pois as políticas adotadas:

Transformam tudo que nos mantém vivos em mercadoria, mandam tudo para fora e quem sofre somos nós, povos indígenas, populações tradicionais e minorias. Falam em tecnologia avançada, mas ela não está servindo para nós e para a floresta. O que chamam de "energia limpa" é para barrar o rio, destruir vidas humanas, peixes, animais, toda a floresta. Então estamos falando também junto com esses que não têm como se defender (CARTA DO I ENCONTRO DE MULHERES MUNDURUKU DO ALTO E MÉDIO TAPAJÓS, 2016, s/p)

O documento frisa também o repúdio às tentativas de dificultar e mudar os processos administrativos para Terras Indígenas como a PEC 215, a Portaria 303 da AGU, o projeto de lei de mineração em Terras Indígenas (PL 1610), assim como a crescente tendência à criminalização de lideranças indígenas e de povos e comunidades tradicionais que lutam pela garantia do bem viver e exigem, por fim, a extinção dos "projetos de morte para a nossa Amazônia, como portos, hidrovia, mineração, hidrelétricas, concessão florestal e outros" (CARTA DO I ENCONTRO DAS MULHERES MUNDURUKU DO ALTO E MÉDIO TAPAJÓS, 2016, s/p).

Nos anos seguintes, a situação se agravou ainda mais para os povos da região. Com a eleição de Jair Bolsonaro (PSL) para a presidência em 2018 a Amazônia passou a estar cada vez mais presente nas manchetes de jornais e nos engajamentos em redes sociais. Em diversas declarações feitas antes, durante e depois da eleição, Bolsonaro apontou uma visão de continuidade das políticas para a região, mas as combinou com 
críticas a ONGs, à demarcação de Terras Indígenas e reconhecimento de comunidades quilombolas, de modo que declarou que caso fosse eleito presidente "não expropriará terras, nem fará demarcação de terras indígenas; ele quer o Brasil fora do Acordo de Paris e extinguir o Ministério do Meio Ambiente" (FUHRMAN, 2018).

O primeiro ano do governo de Bolsonaro ficou marcado, no que diz respeito à Amazônia, às declarações, políticas e críticas recebidas em nível nacional e também internacional. Ainda em janeiro de 2019 , no primeiro mês do mandato, as mulheres indígenas do Baixo Tapajós fizeram denúncias de políticas e ações que ameaçam os povos da região, reafirmando seus modos de vida e suas culturas. A publicação também apresentou críticas ao presidente Bolsonaro:

O Presidente nos comparou a animais no zoológico presos em jaula ao se referir a nossa vida dentro dos nossos territórios tradicionais. Ele faz afirmações absurdas sobre nosso modo de vida e sobre nossos desejos enquanto cidadãs brasileiras. Sim, somos brasileiras! Somos indígenas! Sabemos o que queremos e exigimos o direito de sermos consultadas pelo Estado para elaboração e implementação de políticas públicas! (CARTA DAS MULHERES INDÍGENAS DO BAIXO TAPAJÓS, 2019, s/p)

Krenak (2019) aponta que a relação entre o Estado brasileiro e as sociedades indígenas em relação aos territórios é extremamente problemática. Enquanto o Estado quase reduz a letra-morta o termo terras indígenas, a "máquina estatal atua para desfazer as formas de organização das nossas sociedades, buscando uma integração entre essas populações e o conjunto da sociedade brasileira” (ibid., p. 39). Estão ainda presentes “(...) forças coloniais, que sobrevivem na mentalidade cotidiana de muitos brasileiros a ideia de que os índios deveriam estar contribuindo para um processo de exaustão da natureza" (ibid., p. 41). Identifico este processo de exaustão da natureza com o próprio projeto de nação que tem guiado as políticas no Brasil e que se vê embasado por uma mentalidade racista, como apontado na denúncia feita pelas mulheres indígenas do Tapajós.

Como discutido por González Casanova (2006), é num processo de aliança com as elites locais que a dinâmica do colonialismo interno irá se desenvolver, mas inserida em um plano muito mais amplo, no qual ela faz sentido, objetivando a "aceitação" dessas elites na mesa dos grandes desenvolvidos.

A dinâmica descrita está presente também na fala de Jair Bolsonaro, no momento em que este afirmou em uma entrevista em 8 de abril de 2019 que gostaria que a 
Amazônia fosse explorada pelos Estados Unidos: "quando estive agora com Trump, conversei com ele que quero abrir para ele explorar a região amazônica em parceria. Como está, nós vamos perder a Amazônia, aquela área é vital para o mundo" (DEUTSCHE WELLE, 2019).

O presidente atrelou o "risco de perder a região" a uma possível independência que os povos indígenas poderiam declarar se houvesse a demarcação das Terras Indígenas - argumento recorrente em alguns meios na sociedade a partir de uma problemática interpretação entre autodeterminação, autonomia, independência e soberania e que Gersem dos Santos (2006) aborda de forma profunda. Bolsonaro referese ainda à região como "vital para o mundo", mas diz que pode ser "perdida", destacando também o risco de sua internacionalização.

Aqui precisamos questionar a que mundo o presidente se refere e o que seriam de fato esses riscos: perder a Amazônia para os povos originários significaria perder o acesso à potencialidade de exploração econômica? E, a área é vital para o mundo em sentido econômico ou é possível pensar que seja também vital para os modos de vida dos povos que moram na região de maneira não orientada ao capitalismo?

Suas falas e políticas foram alvo novamente de críticas e discordância do povo Munduruku ainda no início de 2019, no Congresso Mundial de Hidrelétricas (em Paris, França), onde uma coalizão de ONGs e lideranças sociais protestaram:

Agora, o novo governo não é diferente. É o mesmo pariwat (branco) inimigo dos povos indígenas. Estamos aqui mandando o recado: não trocamos e nem negociamos a vida do nosso povo! A cada dia, a cada minuto, o governo Bolsonaro quer acabar com o nosso direito, com nosso território, não queremos que as empresas junto com o governo brasileiro destruam o nosso rio como vocês fizeram com a Usina Hidrelétrica Belo Monte, Teles Pires, São Manoel e tantas outras barragens. Nós caciques, mulheres, pajés, guerreiros e crianças ouvimos os pássaros cantar mais baixo, os rios estão doentes e vocês das empresas estão invadindo e acabando com a Amazônia. (CARTA MUNDURUKU, 2019)

As críticas feitas apontam que o risco de as obras serem retomadas e mais facilmente aprovadas é maior que nos governos anteriores, que também adotaram políticas favoráveis a empreendimentos hidrelétricos na Amazônia. O que diferencia o novo governo é justamente o desmonte dos órgãos responsáveis pela fiscalização e pelas licenças ambientais como o Ministério do Meio Ambiente, o IBAMA e o ICMBio que haviam sido construídas durante décadas a partir da pressão dos movimentos 
sociais. Como consequência da discordância do governo com políticas de fiscalização, foram extintas as secretarias ligadas a políticas sobre mudanças climáticas e propôs-se a extinção do Conselho Nacional do Meio Ambiente (CONAMA), o que foi embargado pelo Supremo Tribunal Federal (STF) meses depois.

O posicionamento do presidente Bolsonaro começou a atrair a atenção internacional e também reações ${ }^{7}$. A preocupação com a destruição iminente da maior floresta tropical do mundo se materializou em muitas reportagens sobre a Amazônia não apenas em nível nacional, mas também com grande repercussão internacional (THE ECONOMIST, 2019; SANDY, 2019; SULLIVAN, 2019; LE MONDE, 2019; RIGBY, 2020; PARAGUASSU, 2019; entre outros). A maioria se deu no auge da crise política do governo na Amazônia, com dados alarmantes sobre desmatamento e queimadas a partir de maio de 2019, mas que continuaram aumentando nos meses seguintes, em que "o SAD detectou 797 quilômetros quadrados de desmatamento na Amazônia Legal, um aumento de $26 \%$ em relação a maio de 2018, quando o desmatamento somou 634 quilômetros quadrados" (COSTA, 2019, s/n).

O teor adotado na maioria das reportagens é de iminente colapso e são feitos recorrentes alertas para a importância da floresta para toda a humanidade. Em algumas, são destacados também os impactos para a população local, especialmente para os povos indígenas, que têm lutado para defender o território. Em outras, adotam-se falas conservacionistas muito associadas a uma lógica de "salvar" por meio de uma intervenção ou de propor um caminho para a região, o que com um diferente objetivo, mas por um caminho similar, acaba por se sobrepor ao agenciamento e luta da população local.

\footnotetext{
${ }^{7}$ Situações como a declaração prefeito de Nova lorque de que não gostaria que houvesse um evento de homenagem ao presidente brasileiro do Museu Americano de História Natural (VITORIO, 2019); a recepção do presidente em Israel com protestos da ONG Greenpeace com dizeres que pediam que o mesmo parasse com a destruição da Amazônia (GREENPEACE BRASIL, 2019); a publicação de uma edição da revista Science com um manifesto assinado por 602 cientistas (KEHOE Et al., 2019) endereçado às instituições europeias e à União Europeia que pedia que os acordos comerciais com o Brasil fossem mantidos apenas com a condição do atendimento a compromissos ambientais, o que, parece já ser uma reação da articulação e das redes de ativismo tanto indígenas como também ambientalistas. Podemos destacar a viagem feita pelo Cacique Raoni na Europa em busca de chamar atenção para a situação dos povos indígenas no Brasil.
} 
Grandes incêndios florestais foram relatados em agosto do mesmo ano em Rondônia e no Acre, no início do período de seca e chamaram a atenção de especialistas pela proporção e incidência maior que em outros anos. A disputa narrativa se deu entre o governo Bolsonaro e ativistas e especialistas, chegando ao momento em que o presidente do INPE, responsável pelo monitoramento, foi exonerado, quando o governo questionou a veracidade dos dados (EXAME, 2019).

Houve desestabilização especial entre o governo da França e o do Brasil, enquanto a reunião do G7 em Biarritz e o discurso do presidente francês, Emmanuel Macron, deram destaque para a importância da região amazônica pela sua biodiversidade e na manutenção do clima. Macron apontou na sua fala que a "Amazônia é nosso bem comum", o que, embora a Guiana Francesa também esteja localizada na Amazônia, foi interpretado como um desrespeito à soberania brasileira pelo governo de Bolsonaro, ao lado da proposta francesa durante a reunião sobre a possibilidade de atribuir um estatuto internacional à região caso "um Estado soberano adotasse medidas concretas claramente contrárias ao interesse de todo o planeta" (AFP, 2019).

A resposta do governo para demonstrar o "cuidado" com a região veio pela criação do Conselho da Amazônia, chefiado pelo vice-presidente General Hamilton Mourão. Em maio de 2020, foi anunciado o uso da garantia de lei e ordem (GLO) por meio do Decreto № 10.341 que autoriza o emprego das Forças Armadas nas terras indígenas, nas unidades federais de conservação ambiental e em outras áreas dos Estados da Amazônia Legal. O anúncio veio junto à publicação de dados de institutos de pesquisa como o IMAZON e o INPE sobre o aumento de $171 \%$ do desmatamento na região em comparação ao mês de abril de 2019, apontando um agravamento da situação (MENEGASSI, 2020).

Em uma reunião ministerial em abril de $2020^{8}$, o Ministro do Meio Ambiente, Ricardo Salles fez menção à pandemia de COVID-19 como uma "oportunidade que nós

\footnotetext{
${ }^{8} \mathrm{O}$ vídeo citado foi publicizado pelo ministro do STF, Celso de Mello, em meio a mais uma crise política do governo Bolsonaro envolvendo acusações do agora ex-ministro da Justiça Sérgio Moro sobre tentativas de intervenção do presidente na Polícia Federal. A reunião ministerial em questão ocorreu no dia 22 de abril de 2020. Os vídeos e o laudo estão disponíveis em: $<$ http://www.stf.jus.br/portal/cms/verNoticiaDetalhe.asp?idConteudo=443959>.
} 
temos, que a imprensa não tá... tá nos dando um pouco de alívio nos outros temas, é passar as reformas infralegais de desregulamentação, simplificação, todas as reformas que o mundo inteiro nessas viagens que se referiu o Onyx..." (STF, 2020, p. 19).

A atuação do governo de Bolsonaro tem trazido, desta forma, uma intensificação de políticas que sempre estiveram presentes no projeto de nação, mas que, sob seu comando, tem se radicalizado e militarizado; desmontando políticas que até então eram alguma garantia ou caminho para se alcançar ou debater propostas. Percebe-se pelas manifestações contrárias ao governo o protagonismo dos povos indígenas que sempre lutaram, em todos os governos, contra um projeto de nação que se mostra incompatível com a sobrevivência da terra e dos povos.

Buscou-se apontar como o projeto de nação desde sua gênese até o atual contexto de agravamento tem como referência um discurso temporal sobre o território e como a Amazônia é localizada em um tempo "passado" que seria trazido ao "presente" por meio da sua exploração garantindo assim um "futuro próspero para a nação" pelo desenvolvimento. O cenário vivido sob o governo Bolsonaro, contudo, tem despertado alerta sobre uma destruição da floresta, sobre o seu fim.

\section{O FUTURO SEM A AMAZÔNIA}

O cenário atual tem provocado preocupação em pessoas de diversos setores, áreas de estudos, movimentos sociais e lideranças internacionais. A partir do imaginário sobre a região, muitos seguiram para exercícios reflexivos sobre uma possível destruição da Amazônia como consequência das políticas adotadas pelo atual governo.

Enquanto na seção anterior foi apresentado o cenário em que se deu a escalada de tais políticas, as críticas e as reações, aqui serão destacadas algumas das reflexões que receberam atenção no mesmo período, em busca de respostas, caminhos e explicações para o futuro que se desenha. Uma das primeiras análises que se uniu às polêmicas e cenário de crise foi a do professor de Relações Internacionais da Universidade de Harvard, o estadunidense Stephen M. Walt (2019) na renomada revista da área, Foreign Affairs.

O artigo assinado pelo professor, intitulado Who Will Save The Amazon (and How)? publicado em 5 de agosto de 2019, no início da crise sobre desmatamento e 
queimadas, afirmava em tom profético que seria apenas uma questão de tempo que grandes potências tentassem impedir as mudanças climáticas por qualquer meio necessário, inclusive por uma possível intervenção da comunidade internacional, quem sabe até mesmo com uso da força. Apesar do texto apenas levantar conjecturas sobre 0 tema, afirmando que, apesar de ser um assunto que merecia um acompanhamento e análises mais específicas, ele considera que não seria o caso de descartar a possibilidade, pois

In a world of sovereign states, each is going to do what it must to protect its interests. If the actions of some states are imperiling the future of all the rest, the possibility of serious confrontations and possibly serious conflict is going to increase. That doesn't make the use of force inevitable, but more sustained, energetic, and imaginative efforts will be needed to prevent it. (Walt, 2019)

A análise do professor, contudo, foi recebida por muitos brasileiros e principalmente pelo governo como uma ameaça declarada, o que, em sentido imaginário, reforçou o temor pela internacionalização da Amazônia, sendo utilizado como uma prova cabal das intenções e ameaças estrangeiras. Podemos insinuar a partir deste caso, das declarações do presidente sobre o uso das Forças Armadas na região e também de outros militares sobre o assunto, que a militarização de políticas no tocante à Amazônia tem se intensificado, remetendo aos próprios tempos da própria ditadura civil-militar.

Para além da reação ao artigo em si, é importante frisar como os seus apontamentos se localizam a partir de uma disciplina - as RI - fundada sob projetos coloniais e imperialistas com noções centradas no Ocidente. Walker (1993) defende que sob o manto da ideia de dentro/fora as $\mathrm{RI}$ reproduzem predominantemente uma associação de ordem/anarquia baseadas em premissas universais do Estado em sentido espacial e temporal, o que podemos relacionar com a elaboração de narrativas de risco de "internacionalização", de defesa da soberania nacional, mas também no recurso utilizado por Walt numa necessidade de "intervenção externa". Assim, por trás da análise política residem noções naturalizadas e universais - soberania, poder, sobrevivência do Estado, hegemonia - que atuam de forma a ser ativadas discursivamente no embasamento de projeto neoimperial e colonial, de agenciamento, silenciamento e violência (AGATHANGELOU E TURCOTTE, 2010). 
Em setembro de 2019, o renomado jornalista e sociólogo santareno e amazônida Lúcio Flávio Pinto, forneceu uma entrevista para Cristina Serra, apresentando sua visão sobre os últimos acontecimentos para a região amazônica, à qual dedicou grande parte da sua vida em reportagens e pesquisas. A chamada da entrevista já trazia em si o tom que marcou a percepção de muitos especialistas sobre a região: "Não há futuro para a Amazônia". O sociólogo embasa sua visão no fato de que "a democracia não chegou na Amazônia. É a região brasileira tardia, a última que se incorporou ao país, e vista de fora para dentro“ (PINTO, 2019).

Lúcio Flávio Pinto destaca ainda como a Amazônia é vista como uma poupança, uma garantia futura, o que reforça o que se tem argumentado sobre a região ser tratada historicamente como receptáculo das expectativas de desenvolvimento do "Brasil-paísdo-futuro". Ele discorre sobre como mesmo com o fim da ditadura, os projetos pensados para a região mantiveram a lógica de desenvolvimentismo predatório e militarização, mesmo na redemocratização. A relação com o tempo é importante na fala de Lúcio Flávio Pinto sobre não haver um futuro para a região.

Outra análise feita no ano de 2019 e publicada na Revista Piauí, por João Moreira Salles e Bernardo Esteves (2019), faz referência a um Mundo sem a Amazônia. A reportagem traz o resultado de simulações do impacto das políticas atuais feita pelos pesquisadores Stephen Pacala, professor de ecologia na Universidade de Princeton, Adalberto Veríssimo, ecólogo, Tasso Azevedo, engenheiro florestal, e João Biehl, antropólogo.

Os pesquisadores partiram de um cenário catastrófico para uma simulação dos impactos que uma transformação da floresta amazônica em pasto significaria para 0 clima, chegando a cenários de diminuição de $25 \%$ das chuvas no Brasil, aumento da temperatura e um prejuízo catastrófico para a agricultura e produção de energia (SALLES E ESTEVES, 2019, s/n). Não focando necessariamente as especificidades da metodologia e dos cenários, destaco dois pontos interessantes para nossa discussão: a quantificação do impacto futuro de acordo com o projeto de nação brasileiro para a região e a própria insustentabilidade do modelo econômico.

O exercício imaginativo pode ser pensado junto a todas as demais análises apontadas e referências utilizadas no percurso desse estudo, referidas às subjetividades 
dos próprios pesquisadores e analistas citados. As projeções de futuro e suas preocupações, são indissociáveis de suas subjetividades: um renomado professor de Harvard exercita sua imaginação na perspectiva intervencionista de grandes potências; o sociólogo e jornalista santareno se vê pessimista aos 70 anos de idade, após décadas de trabalho analisando a região com o agravamento de uma política de Estado que remonta ao século passado. Isto pode ser pensado a partir da afirmação de Ailton Krenak que

Nosso tempo é especialista em criar ausências: do sentido de viver em sociedade, do próprio sentido da experiência da vida. Isso gera uma intolerância muito grande com relação a quem ainda é capaz de experimentar o prazer de estar vivo, de dançar, de cantar. (...) O tipo de humanidade zumbi que estamos sendo convocados a integrar não tolera tanto prazer, tanta fruição de vida. Então, pregam o fim do mundo como uma possibilidade de fazer a gente desistir dos nossos próprios sonhos. (KRENAK, 2019, p. 13)

Assim, "o fim do mundo talvez seja uma breve interrupção de um estado de prazer extasiante que a gente não quer perder. (...) Porque tanto medo assim de uma queda se a gente não fez nada nas outras eras senão cair?" (KRENAK, 2019, p. 60-62), logo, é possível que pensemos também sobre o constante aviso de fim de mundo, ou ausência de futuro nos nossos tempos e como a Amazônia tem sido projetada a partir disso. Podemos retomar a discussão de Agathangelou e Killian (2016) sobre como as RI têm se desdobrado em tentativas de controlar e dominar o tempo e a natureza, e como é notável certo fatalismo metafísico (LAPA, 2018), também resultado da colonialidade enquanto forma de naturalizar as dinâmicas de opressão.

Em A Queda do Céu, obra-diálogo entre o xamã Yanomami Davi Kopenawa e o antropólogo Bruce Albert (2015), o xamã traz uma contraposição ao consenso até aqui utilizado sobre como sociedades ocidentais pensam o futuro:

Os brancos não pensam muito adiante no futuro. Sempre estão preocupados demais com as coisas do momento. (...) Gostaria que os brancos parassem de pensar que nossa floresta é morta e que ela foi posta lá à toa. Quero fazê-los escutar a voz dos xapiri, que ali brincam sem parar, dançando sobre seus espelhos resplandecentes. Quem sabe assim eles queiram defendê-la conosco? Quero também que os filhos e filhas deles entendam nossas palavras e fiquem amigos dos nossos, para que não cresçam na ignorância. Porque se a floresta for completamente devastada, nunca mais vai nascer outra. (KOPENAWA E ALBERT, 2015, p. 65-66)

Ainda que a lógica moderna/colonial seja orientada ao futuro e adote o tempo como linear e progressivo, podemos notar, de acordo com o que traz Kopenawa, que as 
políticas são focadas em um benefício imediato, um lucro e uma exploração presente, ainda que, para justificar tais medidas, utilize-se de um discurso de futuro. $O$ que Kopenawa aponta é como tais políticas têm de fato ameaçado a própria sobrevivência da floresta e todas as vidas com ela interligadas, assim como aquilo que tomamos como "humanidade", demonstrando assim certa incoerência entre o que foi identificado como base fundacional de tais instituições.

Podemos lembrar a perspectiva dos Munduruku sobre o tempo, em que o futuro não existe em si, já que nunca chega a se materializar. Só temos o passado e o presente (MUNDURUKU, 2012). Então ainda que a epidermização da colonialidade esteja enraizada nas instituições e estruturas sociais, as ações do presente são as que geram efeitos e cujo objetivo é o presente em si, pelo viés do lucro da exploração, descrito nas políticas adotadas historicamente para a região amazônica e agravadas nos últimos anos sob o governo de Bolsonaro.

Assim também, é necessário frisar como os eixos da colonialidade se manifestam em todas as formas de se relacionar. Quando Kopenawa indica como os brancos não veem a floresta como vida, isso remete à colonialidade da "Mãe Natureza" (WALSH, 2008) na visão binária natureza/sociedade adotada durante a colonização, que ignorou e reprimiu os conhecimentos e as relações mágico-espirituais-sociais, a relação entre mundos biofísicos humanos espirituais. O chamado feito pelo xamã sobre a queda do céu indica como os modos predatórios que os brancos adotam por meio do Estado têm ameaçado a sobrevivência de todos.

Diferente de um cenário apocalíptico cristão ou hollywoodiano, em que o "mundo" se acaba de uma só vez, Kopenawa alerta para uma queda do céu que leva a desequilíbrios, tragédias, de forma constante, gradual, que não é imediata e que já pode ser percebida. O que ele descreve poderia ser relacionado com a preocupação que assola a humanidade desde sempre, sobre o início e o fim do mundo, recorrente em todas as culturas humanas. Entretanto, é preciso fazer uma ressalva sobre a quais fins e fins do quê nos referimos quando pensamos em tais "fins" e apocalipses. Danowski e Viveiros de Castro (2017) apontam como:

O "fim do mundo" só tem um sentido determinado nestes discursos - só se torna ele próprio pensável como possível -, se se determina simultaneamente para 
quem este mundo que termina é mundo, quem é o mundano ou o 'mundanizado' que define o fim. O mundo, em suma, é uma perspectiva objetiva". (ibid.; p. 37)

A filósofa e o antropólogo demarcam que o próprio ato de pensar o "fim do mundo" envolve uma relação entre o que se considera uma "humanidade" e o "mundo". O que percebemos é que em sociedades ocidentecêntricas existe uma percepção de ameaça ao fim da vida humana em que a natureza teria uma função: possibilitar a continuidade de uma existência humana racional.

Em diversas representações sobre "fins do mundo" é comum perceber que o que se retrata não é o fim de um mundo em sua totalidade, mas a desestabilização de uma sociedade moderna ocidental industrializada, o colapso da forma predominante de organização política e econômica, em que muitos humanos se veem desamparados, é o fim da sua própria referência de mundo. Um exemplo é a fala sobre a Amazônia ser "vital para o mundo", utilizada pelo presidente Bolsonaro ao se referir ao interesse da exploração econômica da região, na qual as ameaças identificadas por uma possível autonomia dos povos indígenas ou de uma "internacionalização" da mesma tem como referência sua própria noção de mundo. Igualmente, o estudo dos pesquisadores sobre um cenário catastrófico da região destacou com ênfase o impacto que seria sentido no setor energético e da agropecuária.

Por outro lado, percebemos como na fala de Kopenawa, mas também das cartas citadas pelos movimentos de mulheres Munduruku no Tapajós, a preocupação é sobre a vida como um todo; a vida da floresta e as vidas que habitam a floresta, a vida dos rios e as que dependem do rio para viver. Enquanto as preocupações ocidentecêntricas remontam à função da Amazônia para o mundo e não a Amazônia enquanto vida em si. Isto pode ser pensado a partir das diferentes percepções que se têm sobre humanidade.

Viveiros de Castro (2017) identifica como a perspectiva adotada por povos ameríndios amazônicos se defronta como a noção filosófica ocidental de separação entre natureza/cultura; irracional/racional/; não-humano/humano. De modo que

Dizer então que os animais e espíritos são gente é dizer que são pessoas; é atribuir aos não-humanos as capacidades de intencionalidade consciente e de 'agência' que facultam a ocupação da posição enunciativa de sujeito. Tais capacidades são reificadas na 'alma' ou 'espírito' de que esses não-humanos são dotados. É sujeito quem tem alma, e tem alma quem é capaz de um ponto de vista. As 'almas' ou 'subjetividades' ameríndias, humanas ou não-humanas, são assim categorias perspectivas, deíticos cosmológicos cuja análise pede menos 
uma psicologia substancialista que uma pragmática do signo. (VIVEIROS DE CASTRO, 2017, p. 323)

Não é o objetivo aqui aprofundar sobre a abordagem em si, mas ela nos ajuda ao ponto que desestabiliza outra ideia normalmente tida como universal e natural na epistemologia ocidental e que perpassa todas as áreas do conhecimento produzidas a partir dela: da hierarquização e separação dos "humanos" sobre a "natureza". É importante traçar como a percepção sobre o tempo, das estruturas políticas e econômicas, sobre o espaço e também noções de "mundo" e "humanidade" têm como base uma hierarquização tida como universal e racional, que justificaria em si, por exemplo, o ímpeto de que pela técnica e a razão é possível reafirmar o caráter humano superior pela dominação da natureza.

Desse modo, é significativo correlacionar a lógica moderna/colonial e as colonialidades do poder e da "Mãe Natureza" embasadas em uma visão de hierarquização e de negação do reconhecimento da humanidade de outrem. Mesmo sob a premissa ocidental do que define a "humanidade", o racismo enquanto um argumento falseado pela ciência impôs tal hierarquização como base para políticas de violência e opressão.

Sendo essas noções fundadas em falsas verdades, percebe-se uma constante neurose com a possibilidade do seu fim iminente, de serem "desmascaradas" envolvendo inclusive um processo de radicalização do extremismo pela sua defesa e reafirmação. De modo que, se quisermos afundar ainda mais nas desestabilizações, o que significaria um "fim" da Amazônia enquanto referência de imaginário nacional? O que isso poderia sugerir para o projeto nacional que instrumentaliza a região enquanto motivo do atraso/perspectiva de futuro/vítima a ser salva?

Podemos pensar com os povos indígenas que as noções espaço-temporais das $\mathrm{RI}$ e dos Estados transbordam traçando diversos caminhos, que ao reorganizar tais referências não incidem em uma mera "criação" de mundos ou "propostas", posto que sempre existiram, mas que apresentam uma multidimensionalidade da percepção do real, deflagrando as ranhuras de bases consideradas muito estáveis e sólidas para o campo. Tais atravessamentos apontam não apenas as instabilidades nas quais políticas 
são apoiadas. Indicam também as incoerências de uma obsessão por um "futuro" que, na prática, fomenta a sua própria destruição e a impossibilidade de vir a ser.

Isto remete a como para o povo Munduruku o futuro não existe (MUNDURUKU, 2012), enquanto para os Aymara o passado está à frente (PAREDES E GUZMÁN, 2014), ao passo que o que tem direcionado as ações no presente tem sido uma constante busca e concretização de um passado (colonial).

No manifesto antifuturista da organização Indigenous Action (2020) é apontado que os povos indígenas vivem no futuro de um passado que não lhes pertence, fruto de uma história de fantasias utópicas e idealização apocalíptica, em uma ordem social global patogênica de futuros imaginados, construída a partir de genocídio, escravização, ecocídio e ruína total. O manifesto nos interpela: "por que conseguimos imaginar o fim do mundo, mas não o fim do colonialismo?" (id.)

\section{CONSIDERAÇÕES TRANSTEMPORAIS}

Chegar a tal ponto de inflexão possibilita que identifiquemos como a colonialidade operou e opera pela produção de subjetividades hierarquizadas, que se impõem não apenas a sujeitos, mas também a instituições, estruturas e lugares, como a Amazônia. Em alguns trechos apresentados, principalmente nas falas do presidente Bolsonaro, nota-se uma referência racializada sobre a região, identificada como indígena, mas como forma de inferiorizar o modo de vida destes povos, localizando a Amazônia em uma ideia de atraso, de primitivo.

A imagem que se projeta sobre os povos indígenas e a região é problemática por negar a diversidade étnica e cultural da região, por operar como um mecanismo de negação da presença indígena em outras regiões do Brasil, como uma oposição às regiões mais "desenvolvidas" e, primordialmente, por carregar uma simbolização da colonialidade enquanto negação da humanidade.

É neste sentido que a lógica de desenvolvimento, inerente à modernidade/colonialidade, faz-se nítida e aponta para o projeto de nação como um caminho homogêneo e de interesse nacional, partindo de uma noção de tempo e espaço ocidentecêntrica, do território enquanto propriedade e fonte de recursos, e do tempo como linear e progressivo, como um destino. 
Noções basilares das RI são atravessadas, neste sentido, por essas premissas. Quando tratamos sobre a Amazônia percebemos a reprodução de tais lógicas nas políticas, discursos e formas de ver a região. Estado, nação, desenvolvimento, soberania e tantas outras referências mais explícitas partem de concepções muitas vezes adotadas pelos estudiosos da área como universais, desde a concepção de mundo, tempo, território e humanidade.

Logo, não pode haver ingenuidade ao se tomar estas referências. Elas são construções de dinâmicas assimétricas e de formas de ver o mundo violentas, que carregam em seu âmago a negação do reconhecimento de outras culturas ao se colocar como universal. Outras perspectivas, como algumas das que foram citadas, permitem a desestabilização de certezas como um convite para rever as limitações das lógicas reproduzidas ao tratarmos de assuntos caros à disciplina.

Enquanto as nossas próprias subjetividades e também as que se referem à Amazônia, por exemplo, são atravessadas por imagens que reforçam estereótipos e intentam fixar o que é impossível de se fixar, os povos e os modos de viver tidos como incompatíveis continuam tensionando com tais premissas. $O$ contraste entre modos de ver e viver tem resultado recorrentemente ao longo da história do País e de outras sociedades em uma sensação de um possível fim do mundo iminente. Mas aí precisamos nos confrontar novamente com o que entendemos por fim e por mundo.

\section{REFERÊNCIAS}

AFP. Incêndios na Amazônia tumultuam relações entre Brasil e França. ISTOÉ Dinheiro, 27 de agosto de 2019. Disponível em:

https://www.istoedinheiro.com.br/bolsonaro-so-aceita-ajuda-do-g7-a-amazonia-semacron-retirar-insultos/ . Acessado em: 12 de janeiro de 2020.

AGATHANGELOU, Anna M. LING, L. H. M. Transforming World Politics: From Empire to Multiple Worlds. New York; London: Routledge, 2009.

AGATHANGELOU, A. M. KILLIAN, K. D. Introduction: Of time and temporality in world politics. In: AGATHANGELOU, A. M. KILLIAN, K. D. (org). Time, Temporality and Violence in International Relations: (De)Fatalizing the Present, Forging Radical Alternatives. London: Routledge, 2016, p. 1-22. 
AGATHANGELOU, Anna M. TURCOTTE, Heather M. Postcolonial theories and challenges to "First-Worldism" IN: SHEPHERD, Laura J. (org.). Gender matters in global politics. Oxford University Press: New York, 2010, p. 44-58.

ANDERSON, Benedict. Comunidades Imaginadas: reflexões sobre a origem e a difusão do

nacionalismo. Trad. Denise Bottman. São Paulo: Companhia das Letras, 2008.

ÂNGELO, Maurício. Fim do Programa Bolsa Verde deixa mais de 50 mil pessoas em situação de extrema pobreza desamparadas. INESC, 2018. Disponível em:

$<$ http://amazonia.inesc.org.br/destaque/fim-do-bolsa-verde-deixa-mais-de-50-milpessoas-em-situacao-de-extrema-pobreza-desamparadas/>. Acessado em 25 de maio de 2020.

BALLESTRIN, Luciana. América Latina e o giro decolonial. Revista Brasileira de Ciência Política, n⒒ Brasília, 2013, pp. 89-117. Disponível em:

$<$ https://www.scielo.br/pdf/rbcpol/n11/04.pdf >. Acessado em 2 de agosto de 2020.

CARTA DO I ENCONTRO DE MULHERES MUNDURUKU DO MÉDIO E ALTO TAPAJÓS-PA, 25 de novembro de 2016. Disponível em:

<https://cimi.org.br/pub/doc/2016-11 Carta I-Encontro-de-Mulheres-Munduruku.pdf>. Acessado em 10 de maio de 2020.

CARTA MUNDURUKU. Paris, 14 de maio de 2019. Disponível em:

https://cimi.org.br/2019/05/nao-trocamos-vida-nossos-filhos-pelas-hidreletricasliderancas-munduruku-franca/. Acessado em 10 de junho de 2019.

CARVAJAL, Gaspar de. ROJAS, Alonso de. ACUÑA, Cristóbal de. Descobrimentos do rio das Amazonas. São Paulo: Brasiliana, Editora Nacional, 1941.

CONGILIO, Célia Regina. IKEDA, Joyce Cardoso Olímpio. A ditadura militar, expansão do capital e as lutas sociais no sudeste paraense. Lutas Sociais, São Paulo, vol.18 n.32, p.79-90, jan./jun. 2014. Disponível em:

$<$ http://www4.pucsp.br/neils/revista/vol.32/celia e joyce.pdf >. Acessado em 4 de agosto de 2020.

COSTA, Stefania. Boletim do Desmatamento da Amazônia Legal (maio 2019) SAD. IMAZON, 21 de junho de 2019. Disponível em:

$<$ https://imazon.org.br/publicacoes/boletim-do-desmatamento-da-amazonia-legal-maio2019-sad/>. Acessado em 2 de janeiro 2020.

CPT. Atlas de Conflitos na Amazônia. Goiânia: CPT; São Paulo: Entremares, 2017.

DANOWSKI, Deborah. VIVEIROS DE CASTRO, Eduardo. Há mundo por vir? Ensaios sobre os medos e os fins. 2ª Ed. Desterro (Florianópolis): Cultura e Barbárie: Instituto Socioambiental, 2017. 
DEUTSCHE WELLE. Bolsonaro quer explorar Amazônia com os Estados Unidos. 8 de abril de 2019. Disponível em: https://p.dw.com/p/3GU5K. Acessado em 04 de junho de 2019.

DUSSEL, Enrique. Europa, modernidade e eurocentrismo. In: LANDER, Edgardo (org). A colonialidade do saber: eurocentrismo e ciências sociais - perspectivas latinoamericanas. Buenos Aires: CLACSO, 2005, p. 25-34.

ESCOBAR, Arturo. La invención del Tercer Mundo: construcción y deconstrucción del desarrollo. 1a. ed. Caracas: Fundación Editorial el perro y la rana, 2007.

EXAME. Presidente do INPE é exonerado após polêmica sobre dados de desmatamento. 2 de agosto de 2019. Disponível em: $<$ https://exame.abril.com.br/brasil/presidente-do-inpe-e-exonerado-apos-polemicasobre-dados-de-desmatamento/>. Acesso em: 11/01/2020.

FANON, Frantz. Os condenados da terra. Trad. José Laurênio de Melo. Rio de Janeiro: Civilização Brasileira, 1968.

FANON, Frantz. Pele negra, máscaras brancas. Trad. Renato da Silveira. Salvador: EDUFBA, 2008.

FIGUEIREDO, Aldrin Moura de. CHAMBOULEYRON, Rafael. ALONSO, José Luis RuizPeinado. Amazônia e história global - Apresentação. Tempo, Dez 2017, vol.23, no. 3, p.504-505.

FOSPA. Foro Social Panamazonico. 2020. Disponível em: <http://www.forosocialpanamazonico.com/pt/>. Acessado em 15 de maio de 2020.

FUHRMANN, Leonardo. Bolsonaro quer exploração da Amazônia "em parceria com os Estados Unidos”. Disponível em: $<$ https://deolhonosruralistas.com.br/2018/10/04/bolsonaro-quer-exploracao-daamazonia-em-parceria-com-os-estados-unidos/>. Acesso em: 02/01/2020.

GERSEM DOS SANTOS, Luciano. O Índio Brasileiro: o que você precisa saber sobre os povos indígenas no Brasil hoje. Coleção Educação Para Todos. Série Vias dos Saberes, volume 1. Brasília: Ministério de Educação Continuada, Alfabetização e Diversidade; Rio; LACED/Museu Nacional, 2006.

GREENPEACE BRASIL. Em Israel, Greenpeace pede urgência na proteção da Amazônia a Bolsonaro. 1ำ de abril de 2019. Disponível em: $<$ https://www.greenpeace.org/brasil/press/em-israel-greenpeace-pede-urgencia-naprotecao-da-amazonia-a-bolsonaro/>. Acessado em 16 de janeiro 2020.

GONDIM, Neide. A invenção da Amazônia. 3ª Ed. Manaus: Editora Valer, 2019. 
GONZÁLEZ CASANOVA, Pablo. Sociología de la explotación. Buenos Aires: CLACSO, 2006.

GUATTARI, Félix. ROLNIK, Suely. Micropolítica: cartografias do desejo. 4a ed.

Petrópolis: Vozes, 1996.

INDIGENOUS ACTION. Rethinking the Apocalypse: An Indigenous AntiFuturist Manifesto. Março, 2020. Disponível em:

$<\mathrm{http}: / /$ www.indigenousaction.org/rethinkingtheapocalypseanindigenousantifuturistmanif esto/>.Acessado em: 2 de agosto de 2020.

KEHOE, Laura. Et al. Make EU trade with Brazil sustainable. Science, 26 Apr 2019: Vol. 364, Issue 6438, pp. 341. Disponível em:

$<$ https://science.sciencemag.org/content/364/6438/341.1 >. Acessado em 10 de maio 2020.

KOPENAWA, Davi. ALBERT, Bruce. A queda do céu: palavras de um xamã yanonami. $1^{\text {a }}$ Ed. São Paulo: Companhia das Letras, 2015.

KRENAK, Ailton. Ideias para adiar o fim do mundo. São Paulo: Companhia das Letras, 2019.

LAPA, Raphael Santos. O fatalismo como estratégia colonial. Epistemologias do Sul, vol. 2 no. 2, p. 144-161, Foz do Iguaçú, 2018. Disponível em: $<$ https://revistas.unila.edu.br/epistemologiasdosul/article/view/1584 >. Acessado em: $1^{\circ}$ de agosto de 2020.

LE MONDE. L'Amazonie, bien commun universel. 2019. Disponível em: $<$ https://www.lemonde.fr/idees/article/2019/08/24//-amazonie-bien-commununiversel 5502406 3232.html>. Acessado em 15 de maio de 2020.

LOUREIRO, Violeta Refkalefsky. Amazônia: Estado, Homem, Natureza. 3a ed. Belém, Pa: Cultural Brasil, 2014.

LOUREIRO, Violeta Refkalefsky. PINTO, Jax Nildo Aragão. A questão fundiária na Amazônia. Estudos Avançados, vol. 19, no. 54, São Paulo, Maio/Agosto de 2005. Disponível em: https://www.scielo.br/pdf/ea/v19n54/04.pdf. Acessado em: 15 de junho de 2019.

LUGONES, María. Rumo a um feminismo descolonial. Estudos Feministas, Florianópolis, vol. 22, no. 3, setembro-dezembro, p. 935-952, 2014.

MUNDURUKU, Daniel. O caráter educativo do movimento indígena brasileiro (19701990). São Paulo: Paulinas, 2012.

MENEGASSI, Duda. Número de queimadas na Amazônia cai enquanto desmatamento 
dispara. O Eco, em 23 de abril de 2020. Disponível

em:<https://www.oeco.org.br/reportagens/numero-de-queimadas-na-amazonia-caienquanto-desmatamento-dispara/>. Acessado em 20 de maio de 2020.

PARAGUASSU, Lisandra. Amazon burning: Brazil reports highest forest fires since 2010. Reuters, 20 de agosto de 2019. Disponível em:

$<$ https://www.reuters.com/article/us-brazil-environment-wildfires/amazon-burning-brazilreports-record-forest-fires-idUSKCN1VA1UK>. Acessado em: 20 de maio de 2020.

PAREDES, Julieta. GUZMÁN, Adriana. El tejido de la rebeldia ¿Qué es el feminismo comunitario? Bases para la despatriarcalizacion. La Paz-Bolivia: Mujeres Creando Comunidad, 2014.

PORTO-GONÇALVES, Carlos Walter. Amazônia, Amazônias. 3a ed. São Paulo: Contexto, 2015.

PINTO, Lúcio Flávio. “Não há futuro para a Amazônia”, diz Lúcio Flávio Pinto. Entrevista por Cristina Serra. Amazônia Real, 23 de setembro de2019. Disponível em:

https://amazoniareal.com.br/nao-ha-futuro-para-a-amazonia-diz-lucio-flavio-pinto/

PINTO, Lúcio Flávio. Brasília locuta. Disponível em:

$<$ https://amazoniareal.com.br/brasilia-locuta/>. Acessado em 20 de maio de 2020.

QUIJANO, Aníbal. Colonialidade do Poder, Eurocentrismo e América Latina. In:

LANDER, Edgardo (org). A colonialidade do saber: eurocentrismo e ciências sociais perspectivas latino-americanas. Buenos Aires: CLACSO, 2005, p. 117-142

SOUZA, Márcio. Amazônia indígena. 1a ed. Rio de Janeiro: Record, 2015.

RIGBY, Sara. Amazon rainforest could take only 50 years to collapse, study suggests. Science Focus, 2020. Disponível em: <https://www.sciencefocus.com/news/amazonrainforest-could-take-only-50-years-to-collapse-study-suggests/>. Acessado em $19 \mathrm{de}$ maio de 2020.

RIST, Gilbert. The history of development: from western origins to global faith. 3 ed., Londres: Zed books, 2008.

SAID, Edward. Orientalismo: o Oriente como invenção do Ocidente. São Paulo: Ed. Companhia de Bolso, 2007.

SALLES, João Moreira. ESTEVES, Bernardo. O Mundo sem a Amazônia. Revista Piauí, 17 de outubro de 2019. Disponível em: <https://piaui.folha.uol.com.br/o-mundo-semamazonia/>. Acessado em 20 de janeiro de 2020.

SANDY, Matt. The Amazon Rainforest is nearly gone: we went to the front lines to see if it could be saved. TIME, 2019a. Disponível em: <https://time.com/amazon-rainforestdisappearing/>. Acessado em 25 de maio de 2020. 
STF. LAUDO NII 1242/2020 - INC/DITEC/PF. Disponível em: <https://videopublicado.s3sa-east-1.amazonaws.com/Degravacao/Laudo Digitalizado.pdf>. Acessado em: 23 de maio de 2020.

SULLIVAN, Zoe. The real reason the Amazon is on fire. Time, 2019. Disponível em: $<$ https://time.com/5661162/why-the-amazon-is-on-fire/>. Acessado em: 20 de maio de 2020.

THE ECONOMIST. Deathwatch for the Amazon: the threat of runaway deforestation. 3 de agosto de 2019. Disponível em: <https://www.economist.com/weeklyedition/2019-0803 $>$. Acessado em 2 de agosto de 2020.

VITORIO, Tamiris. Prefeito de Nova York agradece museu por não sediar homenagem a Bolsonaro. EXAME, 17 de abril de 2019. Disponível em: $<$ https://exame.abril.com.br/mundo/prefeito-de-nova-york-agradece-museu-por-naosediar-homenagem-a-bolsonaro/>. Acessado em: 02 de janeiro de 2020.

VIVEIROS DE CASTRO, Eduardo. A inconstância da alma selvagem e outros ensaios de antropologia. São Paulo: Ubu Editora, 2017.

WALSH, Catherine. Interculturalidad, plurinacionalidad y decolonialidad: las insurgencias político-epistémicas de refundar el Estado. Tabula Rasa.Bogotá Colombia, No.9: 131-152, julio-diciembre, 2008.

WALT, Stephen M. Who Will Save The Amazon (and How)? Foreign Affairs, 5 de agosto de 2019. Disponível em: https://foreignpolicy.com/2019/08/05/who-will-invadebrazil-to-save-the-amazon/. Acessado em: 10 de agosto de 2019.

WALKER, RBJ. Inside/Outside: Relações Internacionais como teoria política. Rio de Janeiro: Ed. PUC-Rio. 1993.

YUVAL-DAVIS, Nira. Gender and Nation. Londres: SAGE, 1997. 